\title{
NON-TRADITIONAL COMPOUNDS FOR CONTROLLING SOME SUCKING PESTS ON STRAWBERY PLANTS IN GREENHOUSE
}

\author{
HABASHY, NADIA H., MONA M. GHALLAB, N. N. ABDEL. MALAK \\ AND E. SH. MANSOUR
}

Plant Protection Research Institute, ARC, Dokki-Giza

(Manuscript received 25 October 2009)

\begin{abstract}
An experiment was carried out at a greenhouse of the Vegetable Research Department-Horticulture Research Institute at Dokki-Giza during 2006 and 2007 years. Five micronutrients i.e. Boric acid $85 \%$, Borax $80 \%$, Cupric oxide Wt $79.5 \%$ Magnesium Sulphate $98 \%$ and Sulfur SC $7.5 \%$ (as a commercial product) were used at two rates; the first $10 \mathrm{grm}$. $/ 1$ liter of water, and the second $5 \mathrm{grm}$./ 1 liter of water for the first 4 compounds in comparison with the commercial product, Del mite SC $7.5 \%$ with recommended rate $1 \mathrm{~cm}^{3} / 1$ liter of water and a second rate $0.5 \% \mathrm{~cm}^{3} / 1$ of liter water against the three Strawberry pests; Tetranychus urticae Koch, Aphis gossypii Glover, and Thrips tabaci Lind. on strawberry plants. The highest reduction comparing with control in motile stages of $T$. urticae in Del mite treatment was (60.99 and 12.600) at the first rate, while, it was (69.50 and 18.77 ) at the second rate, followed by Boric acid (56.26 and 11.10), Borax (51.18 and 9.95), Cupper (42.79 and 7.95) and Magnesium (34.28 and 5.06) at the first rate in 2006 and 2007 years, respectively. A significant difference between control (untreated) and the four other treatments was found.

Key words: Micronutrients - Boric acid- Borax - Cupper Magnesium sulphate - Del mite - Tetranychus urticae - Aphis gossypii - Thrips tabaci.
\end{abstract}

\section{INTRODUCTION}

Several authors investigated the effect of micronutrients (Microelements) or/and Macro elements either as soil treatments or foliar spray on plants.

Buruk (1986) stated that some microelements especially, Zn, Fe and Cupper increased Alkaloid in plant tissues. Alkaloid contains toxic substances protect plant from sucking pests attack.

Harris et al.(1998) found that Potassium fertilizer can significantly reduce two spotted spider mite infestation on cotton Gossipium hirsutum. Mohamed et al.(2001) studied the insecticidal activity of three micro-nutrient foliar fertilizers(chelated Zin, Citric acid and Urea)and two mixed nutrient elements (Grawmore and Stimufol) against $2^{\text {nd }}$ instar larvar of Spodoptera littoralis. All tested fertilizers showed slightly initial toxic effect and high latent toxic effect against larvae especially in cases of Growmore and Stimufol enough to its life cycle. 
Caroline (2004) showed that Boric acid and Borates are naturally occurring compound containing the element Boron. They are often recommended as least toxic pesticides for killing insects, mites, algee, and fungi .Boric acid and Borates kill different types of organisms in different ways .Insects are killed by Boric acid because it acts as a stomach poison and also as an abrasive on the outer surface of the insect. It also absorbs waxes from surface of the insects causing them to dry out. Mansour and Ebaid (2006) showed that mixture of some chelated microelements ( $\mathrm{Zn} \mathrm{12 \% ,} \mathrm{Mn}$ $12 \%$ and Fe12\%) proved to be a good nutritive cotton plants and decreased the rates of infestation with bollworms in cotton plants.

Bostanian et al.(2009) stated that elemental sulfur cause $72.4 \%$ of the young larvae of Galendromus occidentalis (Acari: Phytoseiidae).

The aim of this work is to reduce the using of pesticides, and so it's influence and it's pollution.

\section{MATERIALS AND METHODS}

\section{Material used}

\section{1-Non-Traditional compounds (Micronutrients)}

Four compounds, e.i. Boric acid $85 \%$, Borax $80 \%$, Cupric oxide wt. $79.5 \%$ and Magnesium Sulphate $98 \%$ were used at two rates; 10 and 5 was grm./1liter of water. All these compounds were introduced from El-Nasr Pharmaceutical Chemicals Co.

\section{2- Traditional Compound}

The fifth is the commercial product Del mite (Sufur S 7.5\%) which introduced from Delta Company was used at two rates, the first was $1 \mathrm{~cm}^{3} / 1$ liter of water and the second was $0.5 \mathrm{~cm} / 1$ liter of water.

These experiments were conducted under greenhouse conditions at Vegetable Research Departement -Horticulture Research Institute at Dokki-Giza.

In 220 plastic pots $(25 \mathrm{~cm}$ in diameter) were filled with clay loan soil. Healthy transplants of strawberry were used for planting. Transplants were dipped completely in Rizolox-T solution (tolclofos) for 20 minutes just before planting. No chemical pesticides were used on the area (greenhouse). All pots received the normally recommended agricultural practices during the two successive years (2006 and 2007).

The plastic pots were divided into eleven groups (treatments). Every treatment contained four replicates and each replicate contained five pots. The first treatment was sprayed with water while the other ten were divided into two groups, the first one (included five treatments) were sprayed with the first rate (1 gram./1liter of water) 
and 1 gram / 1 liter of watr for Del mite, and the second five treatments were sprayed with the second rate ( $5 \mathrm{gram}$./liter of water) for microelements and $0.5 \mathrm{gram} . / 1$ liter of water for Del mite. All treatments were sprayed by using hand sprayer furnished with one nozzle. The control ( untreated) pots were sprayed with water.

\section{Population abundance of some sucking pests}

Six week counts of sucking pests were made starting 45 days after nurshing. Samples of five leaves/pot were randomly selected. Direct examination of each selected leaf on its both surfaces were made. Numbers of motile stages of pests were counted and recorded. The following pests were concerned: T. urticae Koch, Aphis gossypii Glover and Thrips tabaci Lind.

\section{Statistical analysis}

The analysis of variance was adopted and the L.S.D. values were calculated to determine the signifance between means of treatments.

\section{RESULTS}

\section{Effect of different treatments on Tetranychus urticae 1-at first rate}

Data presented in (Tables 1 and 2) showed that the highest percent reduction in motile stages of $T$. urticae occured in Del mite treatment was (60.99 \& 12.60), followed by; Boric treatment (52.26 \& 11.10), Borax treatment (51.18 \& 9.95), Cupper (42.79 \& 7.95), and Magnesium treatment (34.28 \& 5.06) in 2006 \& 2007 seasons, respectively.

Statistical analysis in both years of study, showed that there were significant differences between untreated treatment (control) and the other five treatments.

\section{2-at second rate}

Tables; 3 and 4, in both seasons of study showed the highest percent reduction in motile stages of $T$. urticae occured in Del mite treatment was (69.50 \& 18.77), followed by Boric treatment (66.67 \& 16.30), Borax treatment (61.11 \& 14.93), Cupper (55.91 \& 12.88) and Magnesium treatment (45.51 \& 10.14) in $2006 \& 2007$ seasons, respectively.

\section{Effect of different treatments on Aphis gossypii}

\section{At first rate}

Data recorded in (tables, 1 and 2) proved that the highest percent reduction in adults and nymphs of Aphids, in 2006 season, was 36.99 in del mite treatment, followed by Boric (32.88), Borax (26.03) and both Cupper \& Magnesium (20.05), while in the following season, the highest was 20.99 in Del mite, followed by 19.75 in Boric, 17.28 in Borax and $16.05 \%$ in Cupper treatments.

There is a significant difference between untreated treatment (control) and the other five treatments in both two seasons of study. 
NON-TRADITIONAL COMPOUNDS FOR CONTROLLING SOME SUCKING PESTS ON STRAWBERY PLANTS IN GREENHOUSE 
HABASHY, NADIA H., et al., 
NON-TRADITIONAL COMPOUNDS FOR CONTROLLING SOME SUCKING PESTS ON STRAWBERY PLANTS IN GREENHOUSE 
HABASHY, NADIA H., et al., 


\section{At second rate}

In the two season of study, data in (Tables; 3 and 4), showed that the highest percent reduction in adults and nymphs occurred in Del mite treatment (36.99), followed by Boric treatment (32.88), Borax treatment (26.03), both Cupper then Magnesium treatment (20.05) in 2007 season, while, in the 2007season,the percent reduction was 32.97 in both Del mite and Boric treatment gave reduction followed by Borax treatment (28.57), Cupper treatment (23.07) then Magnesium treatment (9.89).

Statistical analysis proved occurrence of significant difference between untreated (control) and the other five treatments in both two seasons of study except Cupper in season 2006 and Magnesium in the two seasons.

\section{Effect of different treatments on Thrips tabaci}

\section{At first rate}

As shown in (Tables 1 and 2), Del mite gave the highest percent reduction in nymphs and adults of Thrips (10.26), followed by Boric (8.97), Cupper (7.69), Borax (3.85) and Magnesium treatment (2.56) in 2006 season, while, Del mite (28.28), followed by, Boric was the highest (24.24), Borax (19.19), Cupper (17.17) and Magnesium (13.13) in 2007 season.

Statistical analysis proved that a significant difference occurred between untreated treatment (control) and the other five treatments in both two seasons of the study.

\section{At second rate}

Data mentioned in (tables, 3 and 4) showed that the highest percent reduction in nymphs and adults of Thrips was in Boric treatment (29.33), followed by, Del mite (25.33), both Borax and Magnesium treatment (21.33) and Cupper treatment (18.67) in 2006 season, while, in 2007 season, Del mite treatment (22.22), Boric treatment (19.19), Borax treatment (14.14), Cupper treatment (13.13) and Magnesium treatment.

There are significant differences between untreated (control) treatment and the other treatments in the two seasons of study.

\section{DISCUSSION}

These findings are in full agreement with those obtained by Abu Awad (1980) on cotton plants and also with those of Nasretdinov (1992) and Habashi (2000) who tested the use of microelements against the major sucking pests on cotton and bean plants respectively. 
In laboratory studies, Habustova and Weismann (2001) showed that Copper caused toxic effects on some insect species ( Agrotis segrtum \& Mamesia brassicae) may causing egg sterility, and morphological abnormalities decreasing fecundity.

Huelsman et al, (2000) clarified a negative correlation between the total sucking pest population affecting sweet potato (Ipomea batatus) and magnesium levels. Ghatwary (2003), proved that foliar fertilizer including microelements could reduce the number of Aphis gossypii and Empoasca decipiens. Caroline (2004) and Ebaid \& Mansour (2006), showed that Boron element had a toxic effect against pests.

Sulfur significantly decreased Tetranychus pacificus population growth rate, acutely toxic on contact to adult females of $T$. urticae and Panonychus ulmi causing 58-100\% mortality .Costello(2007), Stavrinides and Mills (2008), Beers et al.(2009) and Bostanian et al.(2009)] .

\section{REFERENCES}

1. Abou Awad,B.A. 1980. Effect of nitrogen manganese fertilization on the tetranychid mite, Tetranychus urtica koch, and resulting effect on yield of cotton plants. Bulletin de la societEntomologique d'Egypte. 63:95-98

2. Beers, H. Elizabeth ,luis Martinez -Rocha ,Randy R.Talley and E. Dunley. 2009. Lethal, sublethal and behavioral effects of Sulfur-containing products in Bioassays of three Species of orchard mites. J.Econ.Ent.,102 (1): 324-335.

3. Bostanian Noubar J., Howard M.A.Thistlewood, John M.Hardman and Gaetan Ractte. 2009. Toxicity of six novel fungicides and sulphur to Galendromus occidentalis (Acari: Phytoseiidae). Exp.Appl.Acarol.,47:63-69

4. Buruk,G.N. 1986. The influence of microelements on the biosynthesis of alkaloid. Med.Inst. Vitelesk. Rastit, Ressur, 22(2): 272-279.

5. Caroline,C. 2004. Boric acid and Borates. J. of pesticide reform .Vol.24(2):10-15.

6. Costello Michael J. 2007. Impact of sulfur on density of Tetranychus pacificus (Acari:Tetranychidae)and Galendromus occidentalis (Acari: Phytoseiidae) in a central California vineyard. Exp. APPL. Acarol. 42(3)197-208.

7. Ebaid, G.H. and E.S. Mansour. 2006. Relative population abundance of sapsucking pests and associated predators in relation to Non-chemical treatments in cotton field in Egypt. Egyptian, journal of Biological Pest Control, 16 (1\&2), 11-16.

8. Ghatwary,W.G. 2003. Integrated management of certain piercing sucking insects infesting some vegetables crops Ph.D.Thesis, Fac.ofAgric., Zagazig Univ.

9. Habashy, N.H. 2000. Using alternatives to pesticides for the control of mites infesting some vegetable plants. Ph.D. Thesis. Institute of Environmental Sciences, Ain Shams Univ. 
10. Habustova, O. and L. Weisman. 2001. Predominant criteria for evaluation of the toxic effect of $\mathrm{Cd} . \mathrm{Pb}$ and $\mathrm{Cu}$ on insect in agro-ecosystems natural ecosystems: Institute of Experimental Phytopathology and Entomology, Slovak Academy of Sciences, Ekologia- Bratislava, 20(4): 447-453.

11. Harris, F.A., G.R. Tupper and R.E. Furr. 1998. Potassium Fertilizer effect on twospotted Spider mite. Proceeding of the Beltwide Cotton conferences Vol 2: 982-983.

12. Huelsman, M.F., C.A. Edwards, J. Lawrence and D.O.Harris. 2000. A study of the effect of soil nutrient levels on the incidence of insect pests and predators in Jamaican sweet potato (Ipomoea batatas). Proceedings of an international Conference Held at Brington UK., Vol.13 895-900.

13. Mansour,E.S.and G.h.Ebaid. 2006. Joint action of plant growth promoter and microelement on cotton plant's nutrition and on infestation rates with bollworms . J.Agric.Sci.Mansoura Univ.31(3):1621-1631.

14. Mohamed,S.A., A.G. El-Sisi and I.S. Abdel-Wahab. 2001. Insecticidal activity of some foliar fertilizers against cotton leafworm, Spodopteralittoralis (Boisd.). J.Agric. Sci.MansouraUniv, 26(12): 8047-8052.

15. Stavrinides Menelaos C. and Nicholas J.Milla. 2009. Demographic effect of pesticides on biological control of pacific spider mite (Tetranychus pacifcus)by the western predatory mite(Galendromus occidentalis). Biol.Cont.,48(3): 267-273. 


\section{طرق غير كيماوية لمكافحة بعض الافات الماصة على نباتات_الفراولة

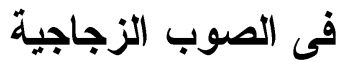

نادية حنا حبثى ، منى محم غلاب ،ناجى ناشد عبد الملاك ، عريان شحاتة منصور

$$
\text { معهُ بحوث وقاية النباتات - مركز البحوث الزراعية - الدقى - الجبزة }
$$

أجريت تجربة بصوبة قسم بحوث الخضر - معهد بحوث البساتين - مركز البحوث الزراعية بالدقى

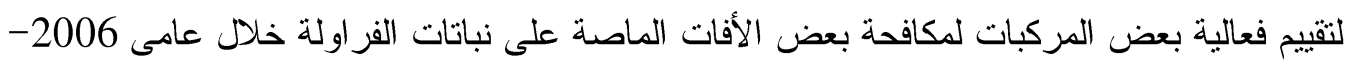

شملت الدراسة تقييم بعض المركبات الغير تقليدية مثل حامض البوريك 85\%؛ البور اكس 80\% ؛أكسيد النحاس 79,5\%؛ كبريتات الماغنسيوم 98\% و تلك المركبات استخدمت بمعدلين الأول

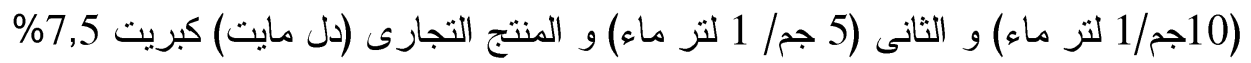

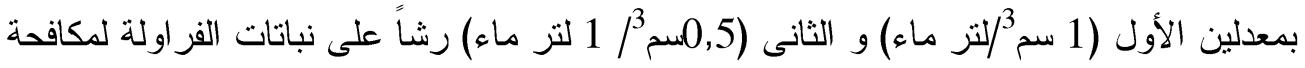
الأفات الماصة وهى العنكبوت الأحمر ذو البقعتين و من القطن و تربس البصل.

دلت النتائج المتحصل عليها على :

1

$$
\text { المعدلين المستخدمين فى عامى الدراسة. }
$$

r - المعدل الأعلى حقق أعلى نسبة خفض فى تعداد الأفات السابقة عن المعدل الأقل فى عامى

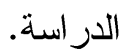

r - المستحضر التجارى دل مايت حقق أفضل النتائج ضد أكاروس العنكبوت الأحمر ذو البقعتين فى كلا المعدلين المستخدمين بعامى الدراسة.

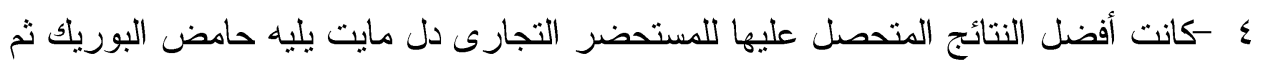
البور اكس و النحاس و اخيراً الماغنسيوم للأفات المستهدفة في عامى الدراسة. 